\title{
Assessment of the Water Quality of the Western Boundary of Kuching Wetland National Park, Sarawak, Malaysia
}

\author{
CHEN-LIN SOO*1, TECK-YEE LING ${ }^{1} \&$ NYANTI LEE ${ }^{2}$ \\ ${ }^{1}$ Department of Chemistry, ${ }^{2}$ Department of Aquatic Science, Faculty of Resource Science and \\ Technology, Universiti Malaysia Sarawak, 94300 Kota Samarahan, Sarawak, Malaysia
}

\begin{abstract}
Kuching Wetland National Park (KWNP) is one of the RAMSAR wetlands in Malaysia, a wetland of international importance. Understanding the water quality of the riverine system that drains the KWNP is crucial for sustainable management of the wetland. Hence, the water quality of Sibu Laut River, which forms the western boundary of the park, is described in this study. Three samplings were carried out during low tide along the western boundary of the wetland. Sub-surface and near-bottom water samples at six selected sampling sites were taken and analysed for physico-chemical parameters. The variations between sub-surface and near-bottom water column of those parameters were detectable and due mainly to the influence of tidal currents. A peak of sub-surface organic phosphorus was observed at station 2 next to the village of Sibu Laut whereas elevated nearbottom organic phosphorus was observed at station 4 near to the shrimp farm. Organic phosphorus represents a significant fraction of the total phosphorus, comprising from $59.76 \%$ to $83.64 \%$ and $62.50 \%$ to $78.67 \%$ for subsurface and near-bottom water, respectively. In contrast, inorganic phosphorus was extremely low at most of the stations. There is a significant correlation between organic phosphorus and chlorophyll $a$, which indicates association of organic phosphorus and phytoplankton in the study area. The present study showed that Sibu Laut River had minimal pollution impact to the wetland, except the elevated sub-surface organic phosphorus near the Sibu Laut Village and elevated near-bottom organic phosphorus near the shrimp farm. Continuous monitoring program is important for early detection of future threats to the water quality of Sibu Laut River.
\end{abstract}

Keywords: Kuching Wetland National Park, phosphorus, physico-chemical parameter, Sibu Laut River, water quality

\section{INTRODUCTION}

Kuching Wetland National Park, KWNP is the first RAMSAR wetland (Ramsar Site No.: 1568) in Sarawak and the fifth in Malaysia. The park covers an area of 6610 ha of the former Sarawak Mangrove Forest Reserve and is located $15 \mathrm{~km}$ from Kuching city. It was classified as a totally protected area and gazetted as a national park in 2002 (Gazette No.: 3512) and listed as a RAMSAR wetland in 2005 (Wetlands International, 2013). Sibu Laut River is one of the rivers that drain the mountainous region at the upper reaches of the wetland and the mangrove swamp within the delta at the estuary. It forms the western boundary of the wetland together with Salak River to the east and Loba Kilong River to the north.

Surroundings of the Sibu Laut River have undergone profound and rapid changes over the past 30 years. Despite of traditional settlement,

*Corresponding author: qianlin1112@gmail.com the river is bounded by new housing development, aquaculture farms, and increasing tourism activities, all of which can have adverse impacts on the river as boundary of RAMSAR site. The population growth and accompanying land-use changes could cause environmental degradation such as pollution and eutrophication, modification and loss of habitat and local communities (Alvarez-Cobelas et al., 2001; Braga et al., 2000; Chandra et al., 2010; Hogland, 1994; Meyer-Reil \& Koster, 2000; Ouyang et al., 2005).

Water quality deterioration is one of the greatest concerns among the environmental degradation. Regular monitoring is an essential tool to gauge the quality of water and to make management decisions for improving or protecting the intended uses. Hence, the water quality information is presented for Sibu Laut River to provide an overview of the western boundary condition of Kuching Wetland National Park. This is necessitated by the 
potential influence of the inflowing water to the wetland since the quality of the inflowing water will greatly influence the status of a wetland. Phosphorus was focused in the present study as phosphorus was one of the main pollutants discharged from domestic wastewater (Ling et al., 2010). Elevated phosphorus concentration was reported near to the villages located along Sibu Laut River (Soo et al., 2014).

\section{MATERIALS \& METHODS}

\section{Study Area and Sampling Stations}

Kuching Wetland National Park (KWNP) is located in western Sarawak with the

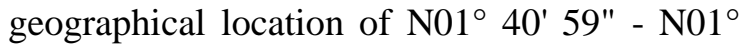
41' 18" / E110 12' 16" - E110 16' 20". The area experiences a humid tropical climate with an annual rainfall of 3,600 - 4,000 $\mathrm{mm}$. The region is not directly exposed to the northeast monsoon. The rainfall is the lowest during June and July, and reaches a peak in December and January. The temperature ranges from $19^{\circ} \mathrm{C}$ to $36^{\circ} \mathrm{C}$, receives an average of 5 hours of sunshine per day (Malaysian Meteorological Department, 2013). The locations of the six sampling stations were shown in Figure 1. The first station was located at the most downstream of Sibu Laut River and station 2 was located at Loba Kilong River near to the Sibu Laut Village. Station 3, 4, 5, and 6 were located along the western boundary of the KWNP which is also the main river of Sibu Laut until the most upper reaches of the river. Station 3 was located near to the Telaga Air town and a public jetty; and station 4 was close to a shrimp farm.

\section{Sampling Techniques}

Sub-surface and near-bottom water samples were collected during low tide for three different sampling periods (May, July, and September) in year 2010. Portable Global Positioning System (GPSMAP® 76CSx, GARMIN) was used to determine the actual coordinates of the sampling stations and to reconfirm the location of the stations during subsequent sampling periods. Water depth and river width were measured using a depth sounder (PS-7, Hondex) and a range finder (Elite 1500, Bushnell) while physico-chemical parameters including salinity, $\mathrm{pH}$, temperature, dissolved oxygen (DO), and turbidity were measured using a refractometer (MR100ATC, Milwaukee), a pH meter with temperature probe (HI 8424, Hanna), a DO meter (HI 9142, Hanna), and a turbidity meter (HI 93703, Hanna), respectively. Three replicates of water

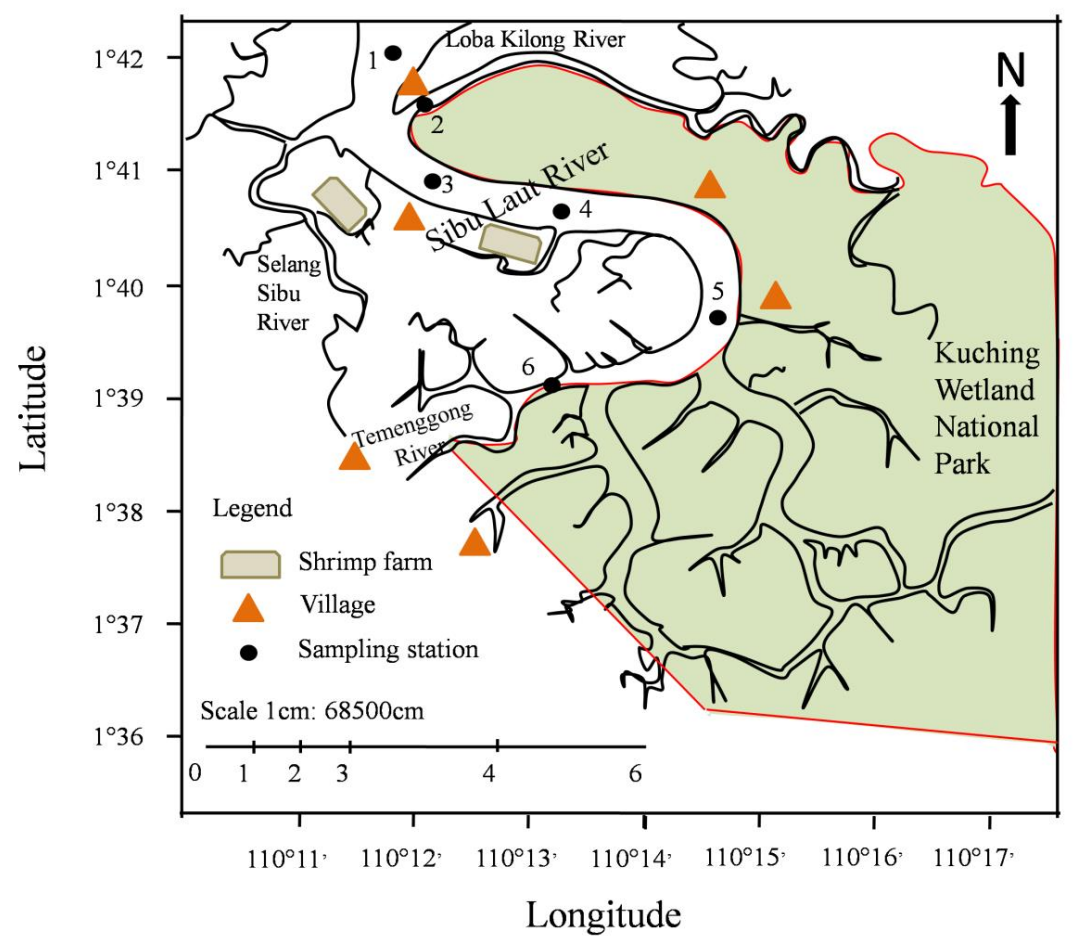

Figure 1. Study area and sampling stations. 
samples were taken from the sub-surface $(\approx 1$ $\mathrm{m}$ below surface water) and near-bottom $(\approx 1 \mathrm{~m}$ above river bed) of the water column by using a two-litre Wildco ${ }^{\circledR}$ Van Dorn water sampler for the determination of chlorophyll $a$, total suspended solids, and phosphorus (total phosphorus, inorganic phosphorus, and organic phosphorus). Water samples were placed in iceboxes and transported to the laboratory for immediate analysis (Jenkins et al., 2005; Parsons et al., 1984).

\section{Analytical Techniques}

Concentrations of chlorophyll $a$ were determined from triplicate samples filtered through $0.7 \mu \mathrm{m}$ Whatman GF/F filters and extracted for 24 hours using $90 \%(\mathrm{v} / \mathrm{v})$ aqueous acetone. Total suspended solids were assayed by filtration of an adequate sample volume through $0.7 \mu \mathrm{m}$ Whatman $\mathrm{GF} / \mathrm{F}$ filter paper and dried at $105^{\circ} \mathrm{C}$. The filtered water samples were then used to determine phosphorus concentrations. Inorganic phosphorus was determined by colorimetric ascorbic acid method by using a spectrophotometer (DR2800, Hach) at wavelength $880 \mathrm{~nm}$ while total phosphorus was determined as inorganic phosphorus after acid digestion of samples. The concentration of organic phosphorus was calculated by the difference of total phosphorus and inorganic phosphorus. All phosphorus concentration was expressed as $\mathrm{mg} \mathrm{PO}_{4} \mathrm{PO}^{3-} \mathrm{l}^{-1}$ in the present study (Jenkins et al., 2005; Parsons et al., 1984).

\section{Statistical Analysis}

The Wilcoxon sign-rank test was used to compare the physico-chemical parameters of sub-surface and near-bottom water samples. The Spearman rank correlation was used to determine the relationship between phosphorus and chlorophyll $a$. All null hypotheses were rejected at $p$ value $\leq 0.05$ unless stated otherwise.

\section{RESULTS}

\section{General Physico-chemical Parameters}

Table 1 summarises the mean, standard deviation, minimum, and maximum values of 12 physico-chemical parameters along the western boundary of Kuching Wetland National Park during low tide. The water depth of the boundary ranged from $4.8 \pm 0.9 \mathrm{~m}$ to $22.0 \pm 3.8$ $\mathrm{m}$ during low tide. The deepest area was observed at station 1 (sea boundary) and the shallowest segment was at station 2 (Loba Kilong River). The river width ranged from $177.4 \pm 17.3 \mathrm{~m}$ to $613.7 \pm 43.9 \mathrm{~m}$. The widest segment was at station 4 while the narrowest was at station 2. Salinity, temperature, $\mathrm{pH}$, and DO in the water are rather consistent at all stations collected during the three sampling periods. Mean values of salinity, $\mathrm{pH}, \mathrm{DO}$, and temperature are $28.0 \pm 0.9 \mathrm{ppt}, 7.75 \pm 0.16$, $4.49 \pm 0.13 \mathrm{mg} \mathrm{O} \mathrm{O}_{2} \mathrm{l}^{-1}$, and $29.8 \pm 0.2^{\circ} \mathrm{C}$, respectively.

Table 1. Mean, standard deviation (SD), minimum (min), and maximum (max) values of the physico-chemical parameters along the boundary of Kuching Wetland National Park for three sampling periods (May, July, and September) in 2010. $\mathrm{N}=6$.

\begin{tabular}{|c|c|c|c|c|}
\hline Parameters & Mean & SD & Min & Max \\
\hline Depth, m & 13.5 & 6.1 & 4.8 & 22.0 \\
\hline Width, $\mathrm{m}$ & 445.8 & 178.2 & 177.4 & 613.7 \\
\hline Salinity, ppt & 28.0 & 0.9 & 26.6 & 29.2 \\
\hline Temperature, ${ }^{\circ} \mathrm{C}$ & 29.8 & 0.2 & 29.6 & 30.0 \\
\hline $\mathrm{pH}$ & 7.75 & 0.16 & 7.52 & 7.96 \\
\hline Dissolved Oxygen, $\mathrm{mg} \mathrm{l}^{-1}$ & 4.49 & 0.13 & 4.27 & 4.61 \\
\hline Turbidity, NTU & 6.37 & 3.26 & 2.94 & 11.1 \\
\hline Total Suspended Solids, $\mathrm{mg}^{-1}$ & 29.8 & 8.7 & 20.9 & 40.6 \\
\hline Total Phosphorus, mg $\mathrm{l}^{-1}$ & 0.029 & 0.004 & 0.022 & 0.034 \\
\hline Inorganic Phosphorus, $\mathrm{mg} \mathrm{l}^{-1}$ & 0.008 & 0.001 & 0.006 & 0.008 \\
\hline Organic Phosphorus, $\mathrm{mg} \mathrm{l}^{-1}$ & 0.021 & 0.004 & 0.014 & 0.026 \\
\hline Chlorophyll $a, \mathrm{mg} \mathrm{m}^{-3}$ & 0.8 & 0.2 & 0.6 & 1.1 \\
\hline
\end{tabular}


Near-bottom salinity steadily increased along the river towards the river mouth. The trend was less apparent for sub-surface salinity (Figure 2). Lower salinity was due to input of freshwater at the upper reaches of the river while the high salinity was due to seawater intrusion from the South China Sea during high tide. Sub-surface salinity was significantly lower than those nearbottom values at all stations (Table 2, $p$ value $\leq$ 0.05 ) except station 4 ( $p$ value $>0.05)$. However, salinity variation between sub-surface and near-bottom water column was differed among stations. Noticeable variation between sub-surface and near-bottom salinity was observed at downstream as shown in Figure 2. Salinity in the near-bottom water was $30.0 \pm 1.0$ ppt at station 1 while the sub-surface salinity was $28.3 \pm 1.5$ ppt. The mean difference of salinity between sub-surface and near-bottom water column at upper reaches of the river was less than 1 ppt (Table 2).

The $\mathrm{pH}$ values of the water were found in the range of $7.52 \pm 0.28$ to $7.90 \pm 0.26$ and $7.53 \pm$ 0.29 to $8.01 \pm 0.24$ for sub-surface and nearbottom water columns, respectively. The $\mathrm{pH}$ increased towards the river mouth except slightly lower $\mathrm{pH}$ at station 2 which is located at the confluence of the Sibu Laut River and Loba Kilong River (Figure 2). Wilcoxon sign-rank test indicated that sub-surface $\mathrm{pH}$ was significantly lower than near-bottom values at all station (Table 2, $p$ value $\leq 0.05$ ).

Dissolved oxygen profiles throughout the Sibu Laut River were generally well aerated, ranging from 4.26 to $4.79 \mathrm{mg} \mathrm{O} \mathrm{O}_{2}^{-1}$. Subsurface DO was significantly higher at station 2 , whereas near-bottom DO was significantly higher at station 4 (Table 2, $p$ value $\leq 0.05$ ). The study area had minimal temperature difference between sub-surface and nearbottom water columns (Figure 2). Temperature of the sub-surface water was $30.0 \pm 0.2^{\circ} \mathrm{C}$ while $29.7 \pm 0.2^{\circ} \mathrm{C}$ at near-bottom water. There was only $0.3^{\circ} \mathrm{C}$ difference between the sub-surface and near-bottom water. Wilcoxon sign-rank test indicated that sub-surface temperature was significantly higher than near-bottom temperature at stations $3,4,5$, and 6 (Table 2, $p$ value $\leq 0.05$ ).

Similar to salinity and $\mathrm{pH}$, water turbidity increased towards river mouth from $2.99 \pm$ 1.40 NTU to $8.48 \pm 0.26 \mathrm{NTU}$ and $2.90 \pm 1.53$ NTU to $13.76 \pm 7.40$ NTU for sub-surface and near-bottom water columns, respectively. Near-bottom water was more turbid at downstream. Wilcoxon sign-rank test also indicated that near-bottom turbidity was significantly higher than sub-surface values at stations 1,2 , and 3 (Table 2, $p$ value $\leq 0.05$ ). Total suspended solids in the study area ranged from $21.5 \pm 7.65 \mathrm{mg} \mathrm{l}^{-1}$ to $29.7 \pm 8.63$ $\mathrm{mg} \mathrm{l}^{-1}$ and $20.3 \pm 5.08 \mathrm{mg} \mathrm{l}^{-1}$ to $53.3 \pm 29.16$ $\mathrm{mg} \mathrm{l}^{-1}$ for sub-surface and near-bottom water, respectively. Figure 2 shows that near-bottom total suspended solids were steadily increasing towards downstream direction while total suspended solids in the sub-surface water were rather consistent at all stations. Total

Table 2. Summary of Wilcoxon sign-rank test and mean differences of 10 physico-chemical parameters between sub-surface and near-bottom water of six stations along the boundary of Kuching Wetland National Park for May, July, and September in 2010.

\begin{tabular}{|c|c|c|c|c|c|c|}
\hline \multirow{2}{*}{ Parameter } & \multicolumn{6}{|c|}{ Station } \\
\hline & 1 & 2 & 3 & 4 & 5 & 6 \\
\hline Salinity, ppt & $(-1.67)^{* *}$ & $(-1.33)^{* *}$ & $(-1.00)^{* *}$ & NS & $(-0.67)^{*}$ & $(-0.44)^{* *}$ \\
\hline Temperature, ${ }^{\circ} \mathrm{C}$ & NS & NS & $(+0.27)^{* *}$ & $(+0.64)^{* *}$ & $(+0.59) * *$ & $(+0.30)^{* *}$ \\
\hline $\mathrm{pH}$ & $(-0.11)^{* *}$ & $(-0.13)^{* *}$ & $(-0.09)^{* *}$ & $(-0.03)^{* *}$ & $(-0.03)^{* *}$ & $(-0.01)^{*}$ \\
\hline Dissolved Oxygen, $\mathrm{mg} \mathrm{l}^{-1}$ & NS & $(+0.17)^{* *}$ & NS & $(-0.23)^{* *}$ & NS & NS \\
\hline Turbidity, NTU & $(-6.01)^{*}$ & $(-5.28) *$ & $(-3.40)^{*}$ & NS & NS & $(+2.08)^{*}$ \\
\hline Total Suspended Solids, $\mathrm{mg} \mathrm{l}^{-1}$ & $(-26.3)^{* *}$ & $(-21.7)^{* *}$ & $(-10.0)^{* *}$ & $(-3.7)^{* *}$ & NS & NS \\
\hline Total Phosphorus, mg $\mathrm{l}^{-1}$ & NS & $(+0.020)^{* *}$ & NS & $(-0.018) * *$ & NS & NS \\
\hline Inorganic Phosphorus, $\mathrm{mg} \mathrm{l}^{-1}$ & NS & NS & NS & NS & $(-0.003)^{* *}$ & $(-0.001)^{*}$ \\
\hline Organic Phosphorus, $\mathrm{mg} \mathrm{l}^{-1}$ & NS & $(+0.020)^{* *}$ & NS & $(-0.017)^{* *}$ & NS & NS \\
\hline Chlorophyll $a, \mathrm{mg} \mathrm{m}^{-3}$ & NS & NS & NS & $(+0.2) * *$ & $(+0.3)^{* *}$ & NS \\
\hline
\end{tabular}

NS = No significant difference.

Mean difference between surface and near-bottom values are shown in parentheses. + indicates surface value averaged higher; - indicates bottom value averaged higher. $\mathrm{N}=3$.

Wilcoxon significance values: $* p$ value $\leq 0.10,{ }^{* *} p$ value $\leq 0.05$ 
suspended solids in the sub-surface water at downstream varied greatly at station 1,2 , and 3 . The most distinct variations were observed at station 1 and station 2. Near-bottom total suspended solids were significantly higher than sub-surface total suspended solids from station 1 to station 4 (Table 2, $p$ value $\leq 0.05$ ).

\section{Phosphorus}

Total phosphorus in the study area ranged from $0.020 \pm 0.009 \mathrm{mg} \mathrm{l}^{-1}$ to $0.043 \pm 0.033 \mathrm{mg} \mathrm{l}^{-1}$ and $0.023 \pm 0.007 \mathrm{mg} \mathrm{l}^{-1}$ to $0.037 \pm 0.016 \mathrm{mg} \mathrm{l}^{-}$ 1 for sub-surface and near-bottom water, respectively. Elevated sub-surface total and organic phosphorus were observed at station 2 whereas higher near-bottom total and organic phosphorus were found at stations 3, 4, 5, and 6. Phosphorus in the water column was mainly organic phosphorus, which constituted more than $70 \%$ of the total phosphorus. Organic phosphorus in the water column contributed $59.76 \%$ to $83.64 \%$ and $62.50 \%$ to $78.67 \%$ of total phosphorus for sub-surface and nearbottom water, respectively. Wilcoxon sign-rank test indicated that sub-surface total phosphorus and organic phosphorus were significantly higher than near-bottom values at station 2 (Table $2, p$ value $\leq 0.05$ ). The concentration of near-bottom total phosphorus and organic phosphorus at the remaining stations were relatively higher as compared to the sub-surface water (Figure 3). The near-bottom total phosphorus and organic phosphorus were significantly higher than sub-surface water column at station 4 (Table $2, p$ value $\leq 0.05$ ). Inorganic phosphorus was extremely low at most of the stations, ranging from $0.004 \pm 0.002$ $\mathrm{mg}^{-1}$ to $0.008 \pm 0.005 \mathrm{mg} \mathrm{l}^{-1}$ and $0.008 \pm 0.005$ $\mathrm{mg} \mathrm{l}^{-1}$ to $0.009 \pm 0.004 \mathrm{mg} \mathrm{l}^{-1}$ for sub-surface and near-bottom water, respectively.
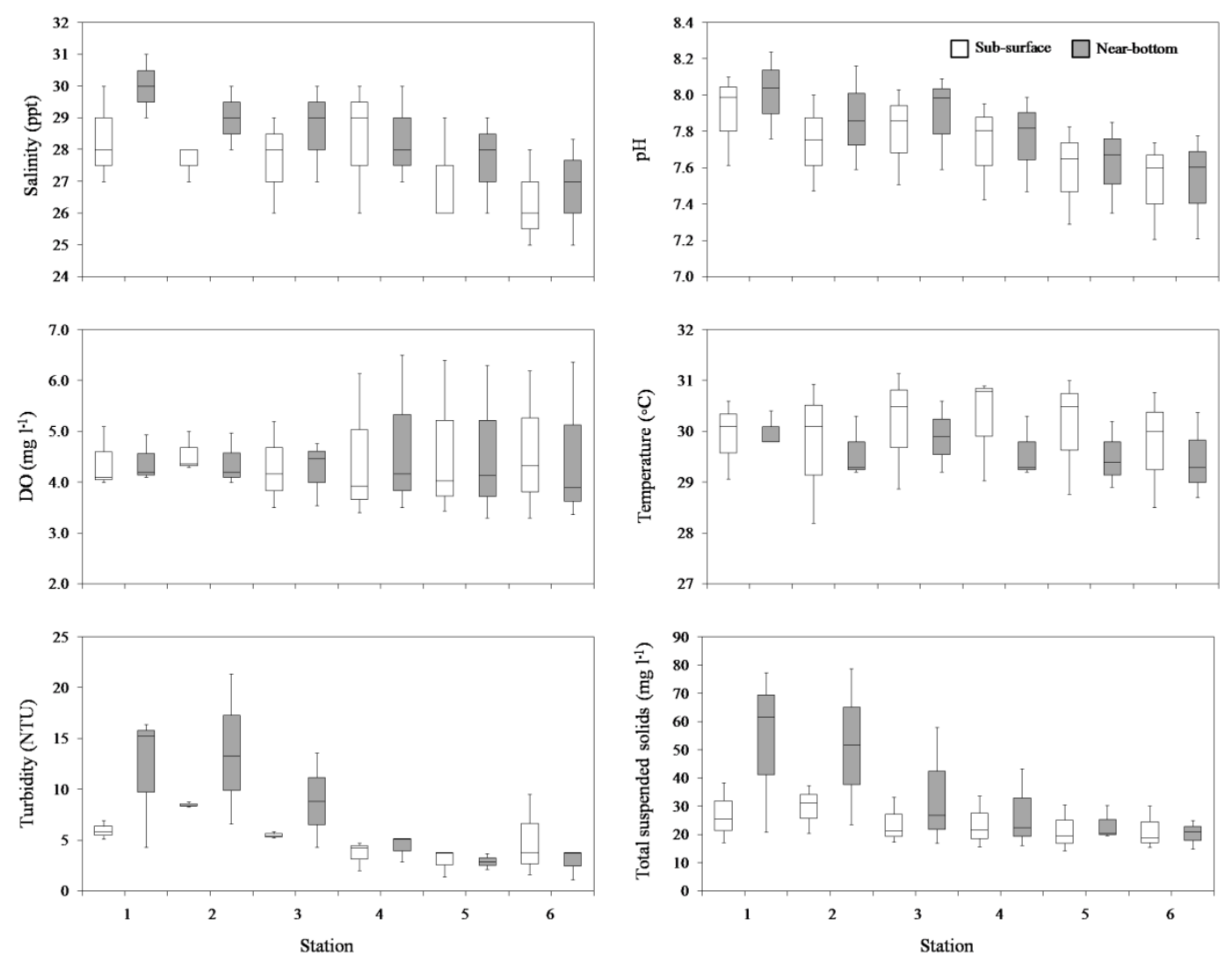

Figure 2. Box-and-whisker plots of physico-chemical parameters that discriminate among the sub-surface and near-bottom water columns of the study area $(\mathrm{N}=9)$. 

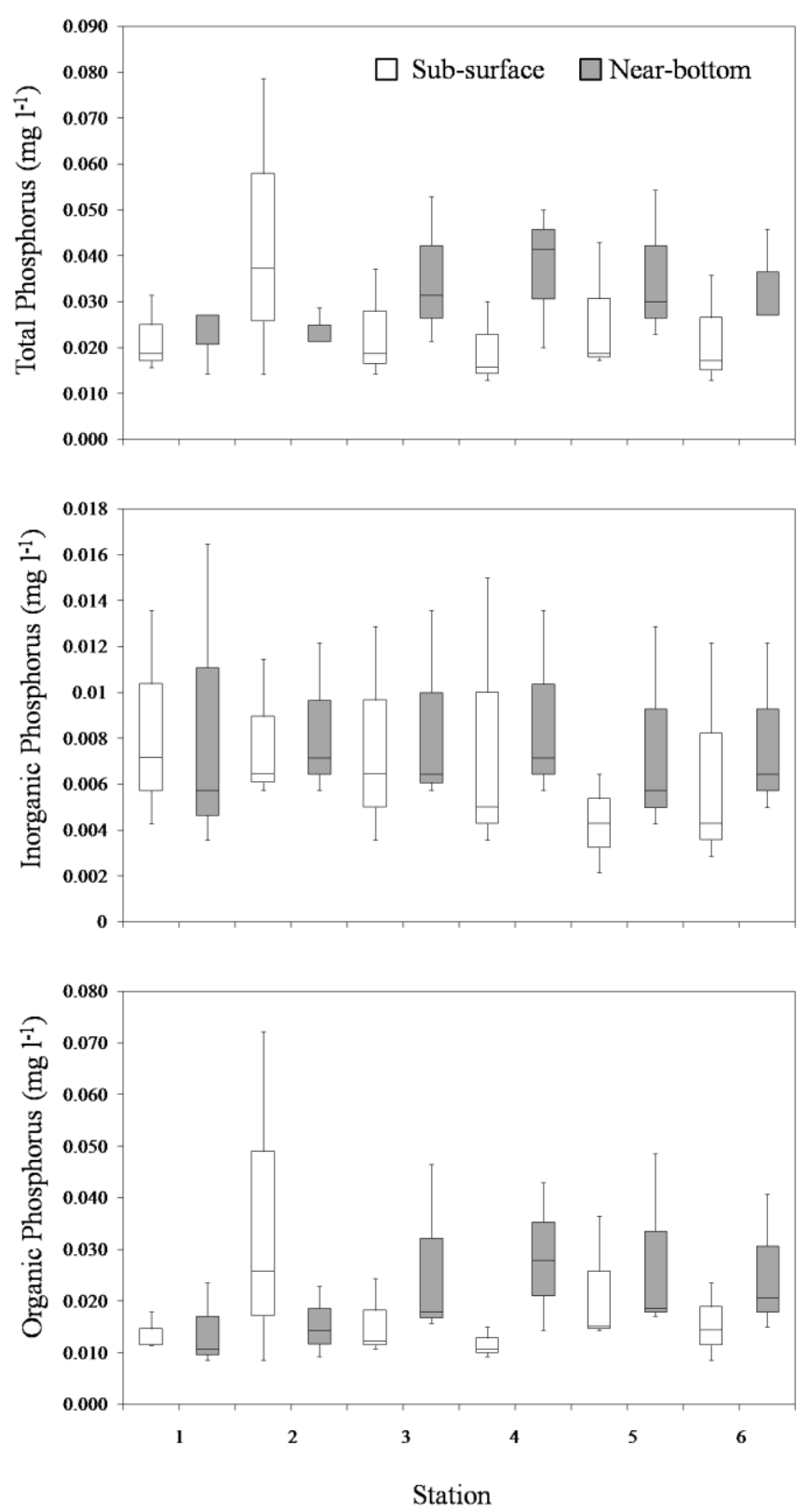

Figure 3. Box-and-whisker plots of phosphorus that discriminates among the sub-surface and near-bottom water columns of the study area $(\mathrm{N}=9)$.

\section{Chlorophyll $a$}

Mean values of chlorophyll $a$ in the study area ranged from $0.7 \pm 0.3 \mathrm{mg} \mathrm{m}^{-3}$ to $1.1 \pm 0.4 \mathrm{mg}$ $\mathrm{m}^{-3}$ and $0.5 \pm 0.3 \mathrm{mg} \mathrm{m}^{-3}$ to $1.0 \pm 0.7 \mathrm{mg} \mathrm{m}^{-3}$ for sub-surface and near-bottom water, respectively (Figure 4). The highest mean value of chlorophyll $a$ was recorded at station 2 for both sub-surface $\left(1.0 \pm 0.4 \mathrm{mg} \mathrm{m}^{-3}\right)$ and near-bottom $\left(1.0 \pm 0.7 \mathrm{mg} \mathrm{m}^{-3}\right)$ water columns, respectively. Table 2 shows that sub-surface chlorophyll $a$ at station 4 and station 5 were significantly higher than near-bottom chlorophyll $a$ ( $p$ value $\leq 0.05)$. Analysis of Spearman rank correlation indicated that there was no significant correlation between subsurface phosphorus and sub-surface chlorophyll $a$ (Table 3, $p$ value > 0.05). Table 4 shows that there are strong negative correlations of near-bottom chlorophyll $a$ with total phosphorus $(\mathrm{r}=-0.886, p$ value $=0.019)$ and organic phosphorus $(\mathrm{r}=-0.928, p$ value $=$ 0.008). 


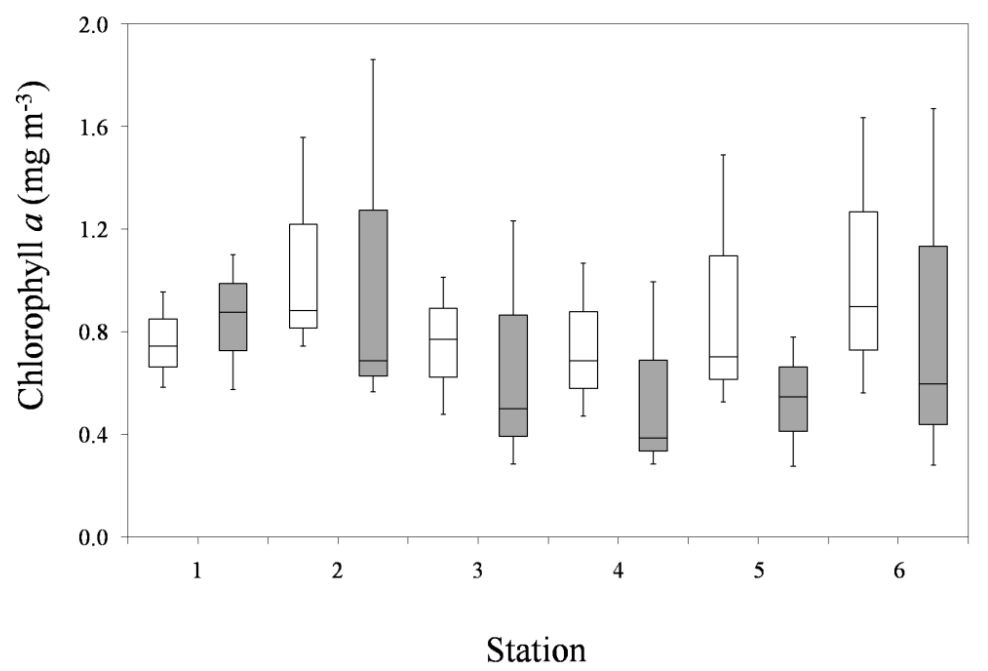

Figure 4. Box-and-whisker plots of chlorophyll $a$ that discriminates among the sub-surface and near-bottom water columns of the study area $(\mathrm{N}=9)$.

Table 3. Spearman rank correlation matrix among the chlorophyll $a$ and phosphorus species in sub-surface water column of Sibu Laut River and tributaries for May, July, and September in 2010 (N = 6).

\begin{tabular}{lllll}
\hline & Chlorophyll $a$ & Total phosphorus & $\begin{array}{l}\text { Inorganic } \\
\text { Phosphorus }\end{array}$ & $\begin{array}{l}\text { Organic } \\
\text { Phosphorus }\end{array}$ \\
\hline Chlorophyll $a$ & 1.000 & & & \\
Total phosphorus & 0.667 & 1.000 & & \\
Inorganic Phosphorus & -0.372 & -0.189 & 1.000 & 1.000 \\
Organic Phosphorus & 0.714 & $\mathbf{0 . 9 8 6}$ & -0.270 & \\
\hline
\end{tabular}

*Significant values $(p$ value $\leq 0.05)$ are indicated in bold.

Table 4. Spearman rank correlation matrix among the chlorophyll $a$ and phosphorus species in near-bottom water column of Sibu Laut River and tributaries for May, July, and September in 2010 (N = 6).

\begin{tabular}{lllll}
\hline & Chlorophyll $a$ & Total phosphorus & $\begin{array}{l}\text { Inorganic } \\
\text { Phosphorus }\end{array}$ & $\begin{array}{l}\text { Organic } \\
\text { Phosphorus }\end{array}$ \\
\hline Chlorophyll $a$ & 1.000 & & & \\
Total phosphorus & $\mathbf{- 0 . 8 8 6}$ & 1.000 & & \\
Inorganic Phosphorus & -0.098 & 0.098 & 1.000 & 1.000 \\
Organic Phosphorus & $\mathbf{- 0 . 9 2 8}$ & $\mathbf{0 . 9 8 6}$ & 0.000 & \\
\hline
\end{tabular}

*Significant values $(p$ value $\leq 0.05)$ are indicated in bold.

\section{DISCUSSION}

Degradation of wetlands has been noticeable for decades. Deterioration in water quality is one of the greatest concerns associated with population growth and accompanying land-use changes. Kuching Wetland National Park which is surrounded by various villages and shrimp farms makes it vulnerable to human activities and susceptible to water quality degradation. This study described the sub- surface and near-bottom water quality of Sibu Laut River which forms the western boundary of Kuching Wetland National Park. Salinity, $\mathrm{pH}$, turbidity, and total suspended solids were significantly higher at the near-bottom water than sub-surface water at most of the stations. In contrast, temperature of sub-surface water was significantly higher than near-bottom water. It is important to note that the differences, while consistent, were small to 
minimal relative to the values observed. For example, temperature exhibited a mean difference of $0.64^{\circ} \mathrm{C}$ or less between subsurface and near-bottom water columns (Table 2 ). This is probably attributable to slight diurnal stratification due to solar heating of sub-surface water. The strong tidal currents cause the significantly higher turbidity and total suspended solids values in the nearbottom water column at the downstream. Interestingly, there was no significant difference between sub-surface and nearbottom temperature at the deepest station (station 1).

Phosphorus is an important element that contributes significantly to agricultural and industrial development, mainly in the use as agricultural fertilisers, animal feed additions, detergents and metal treatment (Ashley et al., 2011; Smit et al., 2009). However, discharges of agricultural and industrial effluents with excessive phosphorus will deteriorate water quality and cause eutrophication (Braga et al., 2000; Hart et al., 2004; Huang et al., 2003; Jarvie et al., 2006). In the present study, measurements of phosphorus concentration revealed sub-surface total phosphorus and organic phosphorus enrichment at station 2 . Since station 2 is near to Sibu Laut Village, the elevated phosphorus concentration maybe due to the wastewater discharged from the village. Phosphorus is an important component of domestic detergents as Ling et al. (2010) reported high loading of reactive phosphorus from the household wastewater into rivers in Kuching, Sarawak. Troussellier et al. (2004) demonstrated that orthophosphate increased in the vicinity of wastewater disposal area in front of the hospital near Senegal River Estuary while Huang et al. (2003) suggested that the land based pollutants near Shenzhen Bay greatly contributed to the increased phosphate concentration in that area. Organic phosphorus concentration in the sub-surface water at station 2 was significantly higher ( $p$ value $\leq 0.05)$ compared to the near-bottom concentration. This further supported the fact that sub-surface water was influenced by the domestic wastewater discharged from the village of Sibu Laut.

Station 3 and station 4 were located near to Telaga Air town, jetty and shrimp farm. No elevated sub-surface organic and inorganic phosphorus concentrations were found at station 3 and station 4 compared to other stations. Station 3 and station 4 were located at the main river of Sibu Laut which is wider and deeper compared to station 2 which is located at the tributary of Sibu Laut River. Hence, the wastewater discharged from the jetty and shrimp farm did not deteriorate the sub-surface water quality of Sibu Laut River. Nevertheless, higher near-bottom total phosphorus and organic phosphorus were observed at stations $3,4,5$, and 6 . The nearbottom total phosphorus and organic phosphorus were significantly higher than subsurface water column at station 4 suggesting that phosphorus from the shrimp farm effluents maybe accumulated in the sediment and re-suspended to the near-bottom water column (Pomeroy et al., 1965).

Phosphorus is one of the nutrients most likely to limit the rate of phytoplankton production (Xu et al., 2008). The present study showed that organic phosphorus may play an important role in controlling primary productivity in Sibu Laut River. Spearman rank correlation calculated for the whole Sibu Laut River showed a close relationship between chlorophyll $a$ and organic phosphorus concentration for near-bottom water column. The negative correlation between organic phosphorus and chlorophyll $a$ at the nearbottom water column suggested that it was rapidly utilised by the phytoplankton community.

Overall, the phosphorus concentration of Sibu Laut River monitored in this study meets the Malaysia Marine Water Quality Criteria and Standard for mangroves estuarine and river-mouth waters (class E), which is $75 \mu \mathrm{g} \mathrm{l}^{-1}$ for phosphate (Department of Environment, 2014). Besides, the chlorophyll $a$ concentration is considered as Class I or 'very good', and equated to oligotrophic and/or mesotrophic status as values of all the chlorophyll $a$ were lower than $2 \mathrm{mg} \mathrm{m}^{-3}$ (Molvaer et al., 1997; Smith et al., 1999). Sibu Laut River as the western boundary of Kuching Wetland National Park had minimal pollution impact to the wetland except the elevated sub-surface organic phosphorus concentration near the Sibu Laut Village and elevated near-bottom organic phosphorus near the shrimp farm. Regular monitoring is 
necessary to guarantee a sustainable use of water resources in the Sibu Laut River and to minimise the eutrophication risk to the Kuching Wetland National Park.

\section{CONCLUSION}

This study provides baseline information on the water quality of Sibu Laut River for the management of the ecosystem as well as the ecosystem for the Kuching Wetland National Park, Sarawak, Malaysia. Variations of the physico-chemical parameters between subsurface and near-bottom water columns were detectable in Sibu Laut River and due mainly to the influence of tidal currents. The phosphorus in Sibu Laut River consists mainly of organic phosphorus whereas inorganic phosphorus concentration was extremely low and nearly undetectable. Elevated sub-surface organic phosphorus concentration near Sibu Laut Village was observed in this study. No noticeable enrichment of sub-surface phosphorus was found at stations near to jetty and shrimp farm, but higher near-bottom organic phosphorus was found at those stations. Chlorophyll $a$ was found to be negative correlated with total and organic phosphorus in near-bottom water of Sibu Laut River. Overall, results revealed an acceptable water quality along the Sibu Laut River according to the Malaysia Marine Water Quality Criteria and Standard. It is concluded that Sibu Laut River had minimal pollution impact to Kuching Wetland National Park.

\section{ACKNOWLEDGEMENTS}

The authors appreciate the financial support provided by the Malaysian Ministry of Science, Technology and Innovation (MOSTI) through E-Science Grant; 06-01-09-SF0026, and Ministry of Higher Education (MOHE) through FRGS Grant; FRGS/07(02)/749/2010 (35), and the facilities provided by Universiti Malaysia Sarawak.

\section{REFERENCES}

Alvarez-Cobelas, M., Cirujano, S., \& SanchezCarrillo, S. (2001). Hydrological and botanical man-made changes in the Spanish wetland of Las Tablas de Daimiel. Biological Conservation, 97: 89-98.
Ashley, K., Cordell, D., \& Mavinic, D. (2011). A brief history of phosphorus: from the philosopher's stone to nutrient recovery and reuse. Chemosphere, 84(6): 737-746.

Braga, E.S., Bonetti, C.V.D.H., Burone, L., \& Filho, J.B. (2000). Eutrophication and bacterial pollution caused by industrial and domestic wastes at the Baixada Santista Estuarine System - Brazil. Marine Pollution Bulletin, 40(2): 165-173.

Chandra, R., Nishadh, K.A., \& Azeez, P.A. (2010). Monitoring water quality of Coimbatore wetlands, Tamil Nadu, India. Environmental Monitoring and Assessment, 169(1-4): 671-676. doi:10.1007/s10661-009-1206-0.

Department of Environment. (2014). Malaysia marine water quality criteria and standard. http://www.doe.gov.my/portalv1/en/infoumum/piawaian-dan-kriteria-kualiti-airmarin-malaysia/301. Downloaded on 15.7.2015.

Hart, M.R., Quin, B.F., \& Nguyen, M.L. (2004). Phosphorus runoff from agricultural land and direct fertilizer effects: A review. Journal of Environmental Quality, 33(6): 1954-1972.

Hogland, W. (1994). Hydrological and environmental effects of agricultural and urban activities in a small Swedish river basin. Nordic Hydrology, 25(4): 247-266.

Huang, X.P., Huang, L.M., \& Yue, W.Z. (2003). The characteristics of nutrients and eutrophication in the Pearl River estuary, South China. Marine Pollution Bulletin, 47(1-6): 30-36.

Jarvie, H.P., Neal, C., \& Withers, P.J.A. (2006). Sewage-effluent phosphorus: A greater risk to river eutrophication than agricultural phosphorus? The Science of the Total Environment, 360(1-3): 246-253.

Jenkins, D., Connors, J.J., Greenberg, A.E., American Public Health Association, American Water Works Association, \& Water Environment Federation. (2005). Standard methods for the examination of water and wastewater (21 $1^{\text {st }}$ edition.). Washington DC: American Public Health Association. 
Ling, T.Y., Siew, T.F., \& Lee, N. (2010). Quantifying pollutants from household wastewater in Kuching, Malaysia. World Applied Sciences Journal, 8(4): 449-456.

Malaysian Meteorological Department. (2013). General climate of Malaysia. http://www.met.gov.my/index.php?option= com_content $\&$ task=view $\&$ id=75\&Itemid= 1089. Downloaded on 3.3.2014.

Meyer-Reil, L.A. \& Koster, M. (2000). Eutrophication of marine waters: Effects on benthic microbial communities. Marine Pollution Bulletin, 41(1-6): 255-263.

Molvaer, J., Knutzen, J., Magnusson, J., Rygg, B., Skei, J., \& Sorensen, J. (1997). Environmental quality classification in Fjords and coastal areas. (p. 36). Norway: Statens Forurensningstilsyn TA-1467.

Ouyang, T., Zhu, Z., \& Kuang, Y. (2005). River water quality and pollution sources in the Pearl River Delta, China. Journal of Environmental Monitoring, 7(7): 664-669.

Parsons, T.R., Maita, Y., \& Lalli, C.M. (1984). A manual of chemical and biological methods for seawater analysis. Oxford: Pergamon Press.

Pomeroy, R.L., Smith, E.E., \& Grant, C.M. (1965). The exchange of phosphate between estuarine water and sediments. Limnology and Oceanography, 10(2): 167172.
Smit, A.L., Bindraban, P.S., Schroder, J.J., Conijin, J.G., \& Van der Meer, H.G. (2009). Phosphorus in agriculture: Global resources, trends and developments (p. 36). Wageningen, The Netherlands: Plant Research International B. V.

Smith, V.H., Tilman, G.D., \& Nekola, J.C. (1999). Eutrophication: Impacts of excess nutrient inputs on freshwater, marine, and terrestrial ecosystems. Environmental Pollution, 100(1-3): 179-196.

Soo, C.L., Ling, T.Y., Lee, N., \& Apun, K. (2014). Assessment of the characteristic of nutrients, total metals, and fecal coliform in Sibu Laut River, Sarawak, Malaysia. Applied Water Science. doi:10.1007/s13201-014-0205-7

Troussellier, M., Got, P., Bouvy, M., M'Boup, M., Arfi, R., Lebihan, F., Monfort, P., Corbin, D., \& Bernard, C. (2004). Water quality and health status of the Senegal River estuary. Marine Pollution Bulletin, 48(9-10): 852-862.

Wetlands International. (2013). Ramsar sites information service. http://ramsar. wetlands.org/. Downloaded on 3.3.2014.

$\mathrm{Xu}$, J., Ho, A.Y.T., Yin, K., Yuan, X., Anderson, D.M., Lee, J.H.W., \& Harrison, P.J. (2008). Temporal and spatial variations in nutrient stoichiometry and regulation of phytoplankton biomass in Hong Kong waters: influence of the Pearl River outflow and sewage inputs. Marine Pollution Bulletin, 57(6-12): 335-348. 